Review

\title{
Mammary gland stem cells and their application in breast cancer
}

\author{
Xing Yang ${ }^{1,2}$, Hui Wang ${ }^{1}$ and Baowei Jiao ${ }^{1}$ \\ ${ }^{1}$ State Key Laboratory of Genetic Resources and Evolution, Kunming Institute of Zoology, Chinese Academy of Sciences, \\ Kunming, Yunnan, China \\ ${ }^{2}$ University of Chinese Academy of Sciences, Beijing, China \\ Correspondence to: Baowei Jiao, email: jiaobaowei@mail.kiz.ac.cn \\ Hui Wang, email: wanghvil@mail.kiz.ac.cn
}

Keywords: mammary gland stem cells, MaSCs, breast cancer stem cells, BCSCs, therapeutic perspectives

Received: June 14, 2016

Accepted: October 14, 2016

Published: October 25, 2016

\section{ABSTRACT}

The mammary gland is an organ comprising two primary lineages, specifically the inner luminal and the outer myoepithelial cell layers. Mammary gland stem cells (MaSCs) are highly dynamic and self-renewing, and can give rise to these mammary gland lineages. The lineages are responsible for gland generation during puberty as well as expansion during pregnancy. In recent years, researchers have focused on understanding how MaSCs are regulated during mammary gland development and transformation of breast cancer. Here, we summarize the identification of MaSCs, and how they are regulated by the signaling transduction pathways, mammary gland microenvironment, and non-coding RNAs (ncRNAs). Moreover, we debate the evidence for their serving as the origin of breast cancer, and discuss the therapeutic perspectives of targeting breast cancer stem cells (BCSCs). In conclusion, a better understanding of the key regulators of MaSCs is crucial for the clinical treatment of breast cancer.

\section{MAMMARY GLAND BIOLOGY}

The mammary gland produces and secretes milk to nourish offspring, and comprises a highly dynamic epithelial structure exhibiting in different development stages [1]. After birth, the mammary epithelia remains quiescent [2]. At puberty, however, the mammary gland expands considerably in response to hormonal cues and other factors to form a highly branched ductal network, a process that is referred to as ductal morphogenesis. In the mammary gland of virgin mice, for example, epithelial proliferation and apoptosis accompany each estrus cycle [3]. During gestation, however, the mammary gland expands further and the alveolar epithelium proliferates rapidly to develop secretory alveoli that are capable of producing milk. During lactation, directional luminal cells synthesize milk proteins and the secreting of oxytocin causes milk to move to the nipple through the branched ductal structure [2]. After lactation, the mammary gland ceases milk production, and the expanded epithelial compartment returns to the 'resting' state of puberty, known as involution [4].
The cycle of mammary gland development is controlled by the synergistic actions of hormones and growth factors, such as the ovarian steroid hormones estrogen and progesterone, and the pituitary growth hormone (GH) and prolactin. During puberty, ductal morphogenesis is driven prominently by estrogen, whereas progesterone activates side branching of the ducts during sexual maturity. Prolactin and progesterone initiate the formation of alveolar bud during gestation, as well as drive milk production during lactation [5]. In addition, estrogen receptors (ER) and progesterone receptors (PR) are critical for mammary gland morphogenesis. Loss of ER- $\alpha$ inhibits branching and elongation of mammary gland ducts, while the development of secretory alveoli is damaged in $\mathrm{PR}^{-1}$ mutant mice $[6,7]$.

During the whole life of a female, the mammary gland undergoes constantly the cycles of proliferation, differentiation, and apoptosis, leading to the remodeling of the glandular tissue. Therefore, researchers suspected the existence of mammary stem cells (MaSCs) for many years, which were finally identified and isolated in mice in $2006[8,9]$. MaSCs can self-renew as well as differentiate 
into different cells in mammary gland development. The self-renewal capacity of MaSCs should ensure and drive the growth and development of the mammary gland during its developing cycle. These features of MaSCs make them a vulnerable target of tumorigenesis. Thus, not only have the characteristics of MaSCs been studied in recent years, but their potential roles during tumorigenesis have also been intensely debated.

\section{MASCS AND PROGENITOR CELLS}

Adult mammary epithelial cells are composed of an inner luminal layer and outer myoepithelial/basal layer, which are thought to arise from a bipotent progenitor during embryonic development (Figure 1). Stem cells are capable of perpetuating themselves through selfrenewal and have the potential to differentiate into all kinds of mature cells to form particular tissues [10]. Transplantation assays have suggested that MaSCs lead to the generation of the two mammary epithelial lineages - the luminal progenitor cells and basal cells $[4,11]$. Luminal progenitor cells can be further subdivided into cells that are restricted to either ductal or alveolar cells. Basal cells consist of an enriched stem/progenitor cell population and myoepithelial cells, which are required for milk secretion during lactation [12].

MaSCs orchestrate the development of the mammary gland during embryogenesis. The identification and the isolation of MaSCs are important for determining their properties and functions. Due to a lack of specific MaSC markers, however, researchers initially utilized stem cell markers that are known in other organs to search for potential stem/progenitor cells in the mammary gland. For example, stem cell antigen1 (Sca-1), a marker of hematopoietic stem cells, was used to isolate mouse mammary gland stem/progenitor cells [13]. Shackleton and colleagues $[8,9]$ used CD29 ( $\beta 1$-integrin, a stemcell marker in skin [14]) and CD24 (heat-stable antigen, a marker of neural stem cells [15]) to enrich MaSCs $\left(\mathrm{Lin}^{-} \mathrm{CD} 29^{\text {high }} \mathrm{CD} 24^{+}\right)$. Ginestier et al. [16] suggested that aldehyde dehydrogenase1 (ALDH1) activity could provide a common marker for both normal and malignant mammary stem and progenitor cells. It has been reported that a combination of ALDH and Sca- 1 can increase the specificity of progenitor populations in COMMA-D cells (murine mammary epithelial cell line) [17]. Recently, Wang et al. [18] identified that protein $\mathrm{C}$ receptor (Procr), marks a unique population of multipotent mouse MaSCs

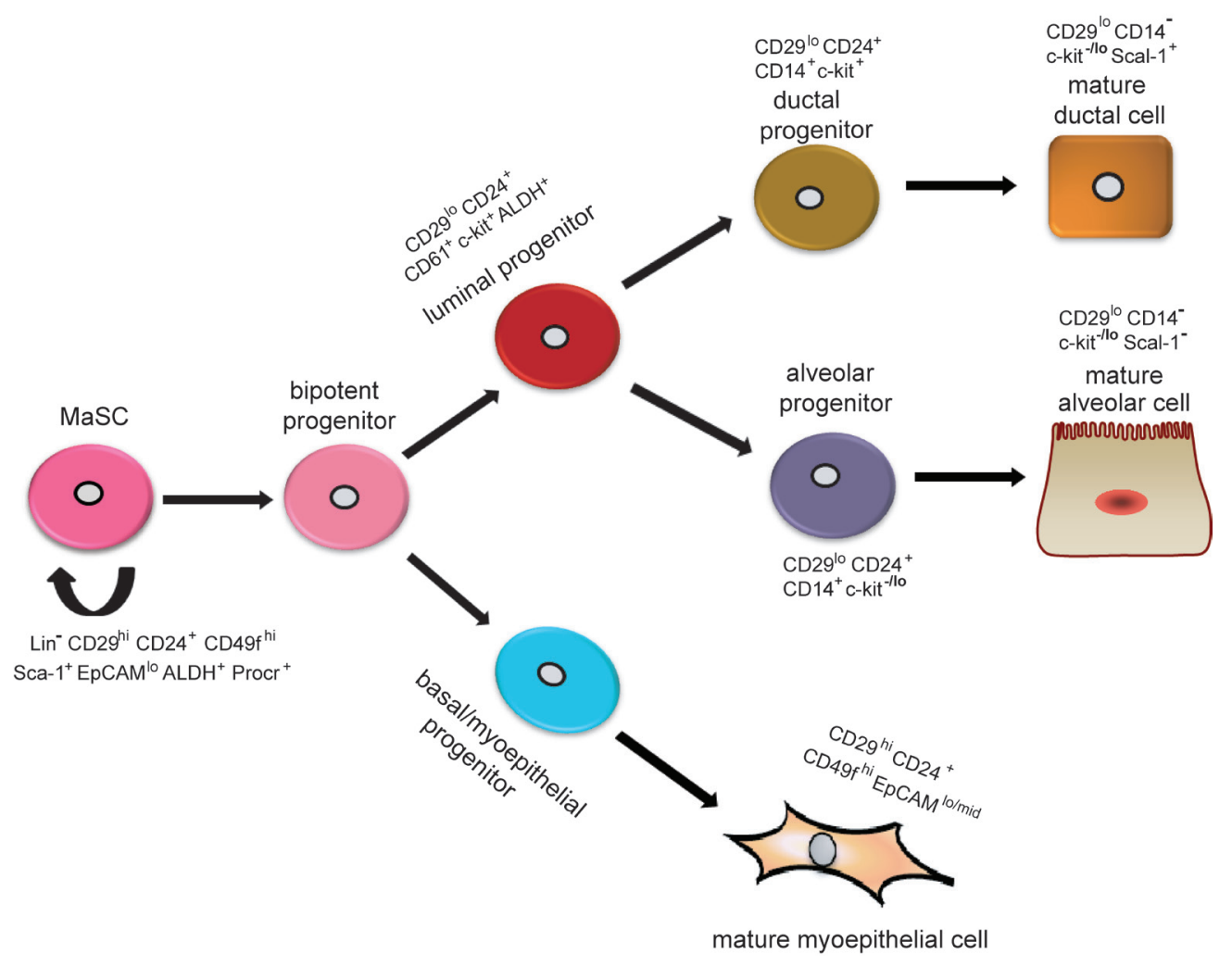

Figure 1: Hypothetical model of mammary epithelial hierarchy and markers of prospectively identified subsets in the mouse mammary gland. A stem cell symmetrically or asymmetrically divides to generate a bipotent progenitor, which, in turn, gives rise to both luminal and basal/myoepithelial progenitor cells. Studies suggest that luminal progenitors differentiate restrictively to either ductal or alveolar cells. In contrast, basal/myoepithelial progenitors differentiate directly to basal/myoepithelial cells that are thought to be enriched for MaSCs. Currently, researchers use surface markers Lin, CD24, and CD29 to isolate basal (Lin-CD24 ${ }^{+}$CD29 hi) and luminal $\left(\mathrm{Lin}^{-\mathrm{CD}} 24^{+} \mathrm{CD} 29^{\mathrm{lo}}\right)$ cells. A specific marker for MaSCs remains unknown. 
in mammary gland, which suggests that Procr $^{+}$cells are important for the development and maintenance of the adult mammary gland.

However, whether MaSCs are multipotent remains a controversial subject. Serial transplantation assays have indicated that a Lin ${ }^{-} \mathrm{CD} 29^{\text {hi }} \mathrm{CD} 24^{+}$cell may reconstitute a complete mammary gland, which implies the single cells are multipotent and have the capacity of self-renewal and multi-lineage differentiation [9]. However, these assays usually do not show such differentiation under physiological conditions [19]. Conversely, genetic lineagetracing experiments can mimic physiological conditions [20]. Using this approach, Van Keymeulen et al. [4] found that the expansion and maintenance of each basal and luminal cell was maintained by the existence of two types of long-lived and lineage-restricted unipotent stem cells, which could directly differentiate into either myoepithelial or luminal lineages, but not being maintained by rare multipotent stem cells. However, lineage tracing experiments do exhibit inherent limitations [21, 22], and thus, the existence of unipotent stem cells remains uncertain. In 2014, using a stochastic multicolor cre reporter combined with new three-dimensional imaging, researchers demonstrated the existence of bipotent MaSCs, and suggested that the unipotent stem cells described in previous studies might represent different progenitor cells [22]. In addition, the Zeng laboratory demonstrated that Procr represents a population of multipotent MaSCs, which are at the top of the mammary epithelial cell hierarchy [18], thereby sustaining that multipotent and unipotent stem cells co-exist in the mature mammary gland. Judging from the descriptions above, mammary epithelial cell hierarchy could be understood as follows: multipotent MaSCs give rise to bipotent stem cells, which differentiate into lineage-restricted progenitors and unipotent stem cells; lineage-restricted progenitors then differentiate into the myoepithelial and luminal epithelial lineages. How MaSCs give rise to progenitor cells or regenerate themselves are subjects to be further investigated. All in all, the purification and characterization of each mammary epithelial cell subpopulation provide an essential framework for defining the regulators and functions of MaSCs and progenitor cells (Figure 1).

The process of mammary gland development requires numerous factors to regulate the function of mammary stem cells at different stages. Knowledge on the mammary gland and MaSCs have significantly contributed to our understanding of mammary gland development and breast cancer. Here, we provide an overview of the

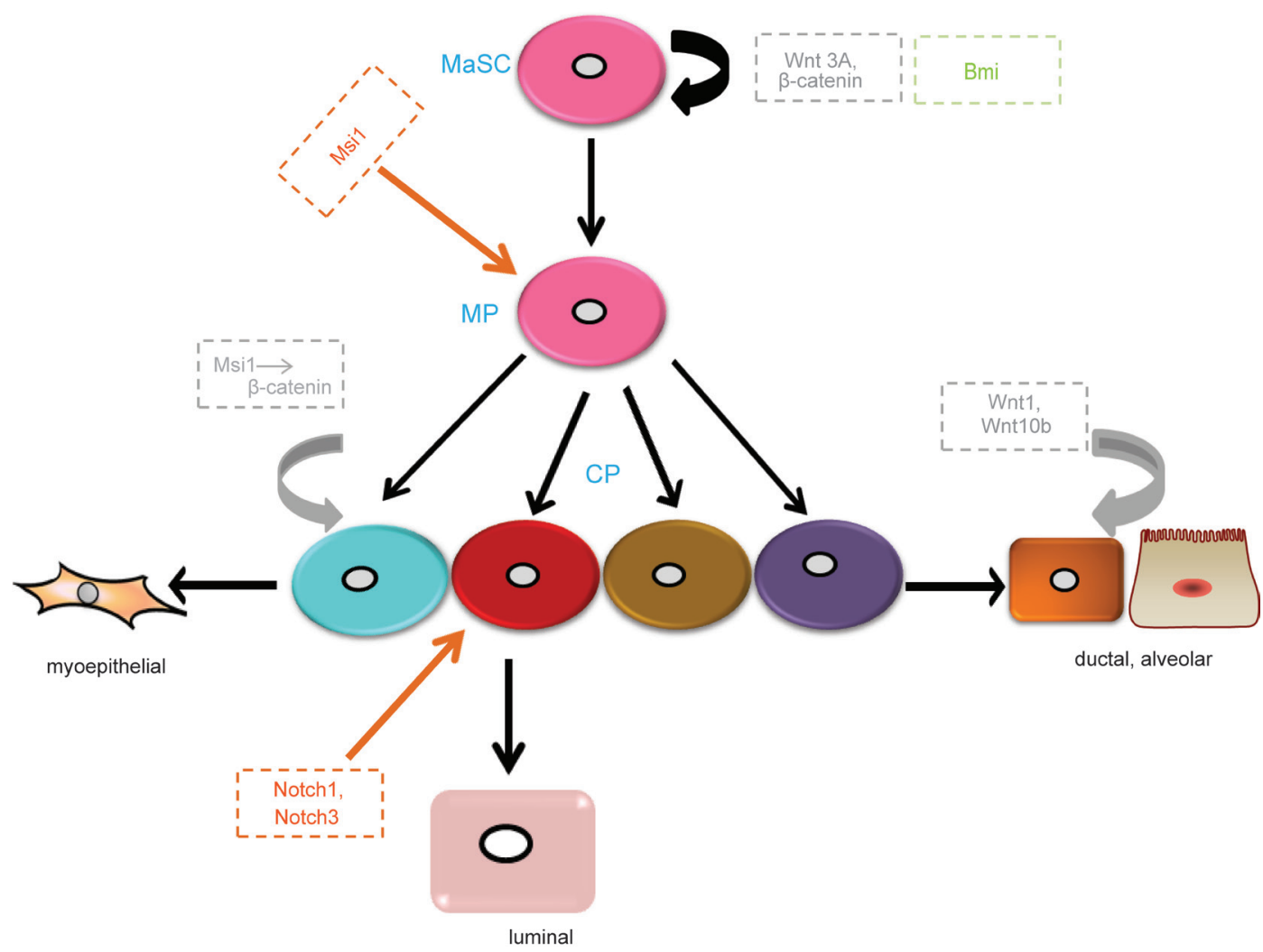

Figure 2: Main regulators of MaSCs in different signaling pathways. Wnt3a regulates the maintenance and self-renewal of MaSCs. Wnt ligands, Wnt1 and Wnt10b, increase ductal branching and alveolar development. Msi1 increases progenitor expansion though increasing $\beta$-catenin. Notch1 and Notch3 increase the proliferation of luminal progenitors. Bmi maintains MaSC self-renewal though Shh signaling. MP, multipotent progenitor; CP, committed progenitor. Grey, Wnt signaling pathway; Orange, Notch signaling pathway; Green, Hh signaling pathway. 
regulatory mechanisms of MaSCs involved in mammary gland development and breast cancer.

\section{REGULATORY MECHANISMS FOR MASCS}

The renewal and differentiation of MaSCs are strictly regulated by factors such as the signal transduction pathways, mammary gland microenvironments, and ncRNAs.

\section{Regulatory pathways of MaSCs}

Once the regulatory pathways of MaSCs are destroyed or aberrantly regulated, cells will abnormally differentiate and proliferate, which could result in breast cancer. Wnt/ $\beta$-catenin, Notch, and Hedgehog $(\mathrm{Hh})$ signaling pathways are broadly involved in the regulation of MaSCs (Figure 2). However, the critical components of these pathways and how they influence mammary stem cell behavior remain unexplored.

Wnt signaling mediated-MaSCs have been described in numerous reviews [23-25]. Most importantly, intracellular Wnt is thought to act through canonical and noncanonical signaling pathways. The canonical Wnt signaling pathway, involving $\beta$-catenin as a key intermediate, is highly conserved in evolution and by far the best characterized of these pathways. The Wnt receptors are composed of Frizzled proteins together with one of the LDL receptor-related proteins (LRP5 or LRP6). Wnt ligands bind to their receptors and act via two cytoplasmic proteins, Disheveled and Axin, to inhibit the activity of a multi-protein complex that includes the tumor suppressor protein adenomatous polyposis coli (APC) and glycogen synthase kinase $3 \beta$ (GSK3 $\beta$ ). The normal function of this complex is to phosphorylate $\beta$-catenin and thereby target it for ubiquitination and proteolysis. Once the activity of the APC-Axin complex is suppressed by Wnt signal transduction, $\beta$-catenin is accumulated in the cytosol and then translocated into the nucleus. Thereafter, $\beta$-catenin forms complexes with DNA-binding proteins of the Tcf/Lef1 family and stimulates the transcription of specific target genes [26]. The overexpression of Wnt and $W n t 10 b$ leads to extreme branching and precocious alveolar development in virgin mice $[27,28]$, suggesting that $\mathrm{Wnt} / \beta$-catenin signaling is essential for normal mammary gland development. Recently, studies have identified that $\mathrm{Wnt} / \beta$-catenin signaling also promotes the proliferation and self-renewal of MaSCs [29]. Using an Axin2-lacZ reporter mouse model, previous research showed that adult mammary glands comprise a population enriched for stem cells, which is response to Wnt signalings. [29, 30]. Wnt3 A greatly increases the clonogenicity of MaSCs. Furthermore, in long-term cell culture at the presence of Wnt3A, MaSCs can retain their self-renewal and differentiation ability in vivo [29]. In addition, constitutively activated $\beta$-catenin leads to excessive stem cell renewal/proliferation [30]. $\beta$-catenin has been indicated as a stem cell survival factor in the mammary gland [31]. Moreover, some proteins regulating the Wnt signaling pathway mediate the function of MaSCs. For instance, Msi1 is a homologue of the Drosophila Musashi protein and a neuroglial stem cell marker, and is expressed in the mouse mammary epithelial cell line and results in progenitor cell proliferation by increasing nuclear localization of $\beta$-catenin [32]. In summary, both Wnt signaling itself and its relevant proteins are involved in the regulation of MaSCs functions. Aberrant Wnt signaling through silencing of endogenous inhibitors or overexpression of Wnt ligands have been reported in human breast cancer [29, 33].

The Notch signaling pathway consists of ligands, receptors, and target genes. The Notch receptor has four homologs in mammals (Notch1-Notch4). The structure of the Notch receptor consists of a Notch extracellular structural domain (NEC) and transmembrane domain/ Notch intracellular structural domain (NICD). All Notch ligands are single-stranded transmembrane proteins, named Delta-like 1, Delta-like 3, Delta-like 4, Jagged 1, and Jagged 2 [34-36]. Notch signaling transduction is initiated and activated by ligand binding, which involves proteolysis and endocytosis of the receptor. When the receptor is activated, it liberates the NICD, which is translocated into the nucleus and subsequently interacts with the DNA-binding protein CSL to induce the transcription of target genes [37, 38]. The expression of Notch ligands, receptors, and transcriptional targets are important regulators of mammary stem cells, luminal progenitors, and mature luminal enriched populations. In the mammary gland, Notch receptors are expressed in the luminal compartment. Here, we mainly focus on Notch1 and Notch3. By lineage tracing, Rodilla and colleagues [39] demonstrated that Notch1 is expressed in $E R \alpha^{\text {neg }}$ luminal progenitors and increases the selfrenewal capacity of MaSCs. Notch3, a receptor associated with triple negative breast cancer [40], is involved in the maintenance of stem cells in other tissues [41-43]. Lafkas et al. [44] revealed that Notch3 is expressed in luminal progenitor cells. In addition, they found that proliferation of these cells was controlled by Notch3 activity using gain-of-function Notch3 mutant mice. However, knockdown of the Notch effector Cbf-1 in MaSC-enriched populations resulted in a significant increase in mammary repopulation capacity, demonstrating that downregulation of the pathway leads to MaSCs expansion. While, luminal progenitor cells expand and self-renew, eventually leading to the development of tumors in the presence of continual Notch signaling [45]. In addition, as mentioned above, overexpression of Msi1 leads to increased proliferation of progenitor cells; however, it maintains Notch activity and the transcription of downstream ligands and effector genes 
by inhibiting Numb (a cell fate determinant that interacts with Notch-1) [32]. Thus, another mechanism of Msi1 promoting mammary progenitor/stem cell proliferation could be the upregulation of Notch signaling. In summary, the Notch pathway plays a key role in MaSC expansion and luminal cell-fate commitment.

Hh signaling was first identified in Drosophila, where $\mathrm{Hh}$ is a segment polarity gene that regulates embryonic patterning [46]. It is an evolutionarily conserved system that controls patterning and cell fate from Drosophila to humans. The crucial components of the Hh signaling pathway are comprised of ligands (Sonic hedgehog, Shh; Indian hedgehog, Ihh; Deser hedgehog, Dhh), receptors (Patched-1 and -2 as well as Ptch1 and 2), effectors (Smoothened, Smo), and transcription factors (Gli1-3) [47]. In the absence of Hh ligand binding, the receptor Ptch localizes at the primary cilium and inhibits the co-receptor Smo, which is an essential positive mediator of the entire pathway, resulting in the phosphorylation and cleavage of transcription factors Gli2 and Gli3. These cleaved transcription factors act as repressors of target gene transcription. Once Hh binds to its receptor, Ptch no longer represses Smo and consequently Gli2 and Gli3 are not cleaved, thus activating Hh target genes [48]. Studies have described that $\mathrm{Hh}$ signaling is involved in the regulation of MaSCs. For instance, Ptch1, Gli1, and Gli2 are highly expressed in normal mammary stem/progenitor cells and are down regulated in differentiated cells [49]. Fiaschi et al. [50] reported that Gli1-induced tumors are involved in the expansion of epithelial cell populations that express putative progenitor cell marker cytokeratin 6 . The Hh signaling pathway also targets other transcription factors in MaSCs. For example, the activation of the Hh signaling pathway increases the self-renewal and proliferation of MaSCs by stimulating transcription factor Gli and polycomb gene Bmi-1 [51]. Bmil is a downstream effector of Shh signaling [51], and its loss has an inhibitory effect on the proliferation and differentiation of MaSCs [52].

Other regulatory pathways of MaSCs include signal transducer and activator of transcription-5a and $-5 \mathrm{~b}$ (STAT5), which are both highly conserved. Although the STAT5 transcription factors are not important for MaSCs to reconstitute a functional mammary gland, Yamaji and colleagues [53] showed that the absence of STAT5 results in impairment of alveologenesis and lactation due to a reduced number of alveolar luminal progenitor cells in the virgin state. In addition, loss of STAT5 does not affect $\mathrm{CD} 1^{+}$luminal ductal progenitor populations, but does cause a decrease in $\mathrm{CD}^{+} 1^{+}$luminal alveolar progenitor cells [54]. The p53 pathway also plays a considerable role in the control of stem cell function in various tissues, including the mammary gland $[55,56]$. Deletion of p53 enhances the self-renewal capacity of MaSCs via modulation of the Notch pathway [57], inhibition of rapid cell cycle progression [55], and prevention of epithelial- to-mesenchymal transition (EMT) program activation [55]. However, the precise molecular mechanism between p53 loss and stemness is unknown, which needs further investigation.

\section{Mammary gland microenvironment}

Somatic stem cells are sustained and controlled by the surrounding microenvironment (niche), which is locally restricted to supporting the self-renewal of stem cells and preventing their differentiation. Similarly, MaSCs are also stably maintained within specific microenvironments. How does the microenvironment maintain tissular growth, cellular differentiation, and development of the mammary gland? As discussed below, a complex network exists among luminal cells, basal cells, stroma, and their microenvironments, which involves signaling from extracellular matrix (ECM) molecules, stromal-derived growth factors, and cytokines, and proteolytic enzyme activity in the microenvironment.

In mammary microenvironment, steroid hormones profoundly influence the behavior of MaSCs [21, 58], despite a lack of estrogen and progesterone receptors $[21,59]$. Asselin-Labat and colleagues [21] found that ovariectomy markedly reduced MaSCs numbers in vivo, while treating with estrogen plus progesterone in mice, the activity of MaSC was increased [21]. Using the mouse estrus cycle as a model, Joshi et al. [58] demonstrated that alternation in MaSC numbers was associated with the estrus cycle, while progesterone was at maximal levels during diestrus. To examine the effect of progesterone on MaSCs, they also injected hormones to bilaterally ovariectomized mice and found that treatment with 17ß-estradiol plus progesterone induced MaSC amplification [58]. In addition, Lombardi et al. [60] demonstrated that the $\mathrm{GH}$ receptor (GHR) was expressed in normal human mammary epithelia, and progestin treatment increased $\mathrm{GH}$ secretion, resulting in an increased number of cycling stem/progenitor cells.

Cytokines and growth factors are important mediators of MaSCs in the mammary gland microenvironment. Receptor activator of nuclear factor$\kappa \beta$ ligand (RANKL) has been indicated in mammary progenitor cell maintenance [61], and is a downstream effector of progesterone-mediating mammary lobuloalveologenesis [62]. Furthermore, progesterone stimulation has been shown to promote mammary epithelial proliferation by activation of RANKL in mice $[21,62]$. Pregnancy leads to a hormonal environment, which influences the function of MaSCs. Although hormonal control is complex, progesterone has a prominent role in the establishment and maintenance of pregnancy. Asselin-Labat et al. [21] demonstrated that RANKL is a key mediator of MaSC function through paracrine in established pregnancy. In addition, Pellegrini et al. [61] also found that constitutive RANK expression 
breaks the balance between basal and luminal cells, leading to activation and expression of miR-146b in MaSCs and luminal progenitors . R-Spondin1 (Rspo1) is a potent WNT signaling enhancer and stem cell renewal mediator [63]. The inhibition of RANK signaling results in the activation of Rspo1, which suggests it is a key downstream effector of RANK on the functional regulation of mammary progenitors [64]. Similarly, Cai et al. [65] identified Rspo1, a novel hormonal mediator in the mammary gland, can promote MaSC self-renewal cooperated with Wnt4 through Wnt/ $\beta$-catenin signaling. The transforming growth factor- $\beta$ (TGF- $\beta$ ) superfamily has an important role in mammary gland development. Bone morphogenetic protein (BMP) is a soluble member of the TGF- $\beta$ superfamily, and controls the function of stem cell regulation in many systems, including the mammary gland [66]. Chapellier et al. [67] demonstrated that BMP2 is an important regulatory factor of the stem cell niche, and controls the luminal differentiation of mammary progenitors. The ECM is a main regulator of epithelial function. In the mammary gland, myoepithelial cells exist in a specialized layer of the ECM, called the basement membrane (BM). Using microenvironmental protein microarrays, Studies have shown that ECM molecules influence mammary progenitor cell fate decisions $[1,68]$. For example, laminin-1 inhibits the growth of mammary progenitor cells and maintains them in a quiescent state, whereas P-cadherin compels the differentiation of progenitor cells into myoepithelial cells [69]. Conversely, cell-cell connection, or expression of E-cadherin, facilitates progenitor cells differentiation into luminal epithelial cells [1]. Thus, the expression of the above microenvironmental proteins could mediate progenitor cell fate. Proteolytic actions remodel the ECM and stroma as well as release growth factors and cytokines. Thus, proteases are important for mammary gland development and function. The well-known enzymes in the condition of mammary gland development and differentiation are matrix metalloproteinases (MMPs), which are a family of extracellular zinc-dependent endopeptidases that contribute to a wide range of physiological and pathological processes $[5,6]$. MMP3/stromelysin-1 is mostly produced by stromal fibroblasts and can promote epithelial-branching morphogenesis during puberty [7]. Using transplantation and mammosphere formation assays, researchers have also demonstrated that overexpression of MMP3 promotes MaSC self-renewal and differentiation [1]. In accordance with this, MMP3-deficient mutant mice reveals decreased numbers of MaSCs and diminished mammary-reconstituting activity [1].

\section{ncRNA regulation of MaSCs}

Non-coding RNA is a kind of RNA molecule that is transcribed from the genome, but does not encode proteins. In recent years, ncRNAs have become an increasingly hot topic of research. Regulatory ncRNAs can be classified into two classes according to their length: small ncRNAs, which contain short ( $<200 \mathrm{nt})$ RNA species, such as small-interfering RNAs (siRNAs), piwi-interacting RNAs (piPNAs), small nucleolar RNAs (snoRNAs), and microRNAs (miRNAs); and long ncRNAs (lncRNAs), which contain several types of transcripts $100 \mathrm{~s}$ to $1000 \mathrm{~s}$ of nucleotides long [70]. They participate in the regulation of all fundamental processes of development and tissue homeostasis, for instance, stem and progenitor cell regulation, cell-fate commitment, and differentiation. Next, we will focus on the role of ncRNAs (especially miRNAs and lncRNAs) in the regulation of MaSCs.

MicroRNA is a small ncRNA molecule and interacts with the 3' untranslated regions (3'UTRs) of targeting messenger RNAs to suppresses gene expression . They regulate numerous biological processes, including cell proliferation, stem cell maintenance and differentiation. The essential function of miRNAs in the various stages of mammary development is now recognized, and they have a main role in the regulation of developmental processes, proliferation, differentiation, and apoptosis. The expression of miRNAs in different cellular sub-populations has also been determined. For instance, miR-146b was found to be upregulated in basal cells and enriched in alveolar progenitor cells isolated from the mouse mammary epithelial cell line COMMA-1D [71-73]. In addition, miRNAs have also been described in the functional regulation of MaSCs. In limiting dilution transplantation experiments of primary mammary epithelial cells, passivation of the miR-193b locus, which targets STAT5 in mice mammary epithelia, resulted in elevated mammary stem/progenitor cell activity [74]. Using a small RNA library, Ibarra et al. [17] found that miR-205 and miR-22 were consistently enriched in the progenitor population, suggesting that they might be important for the identity of basal cells. For example, inhibition of miR-205 converts the epithelial phenotype to the mesenchymal phenotype (EMT) and promotes the stemness phenotype in mammary epithelial cells. Furthermore, miR-205 has also been implicated in the polarity of stem cell division and cell fate through concerted regulation of Zeb1 and Notch2 [75]. The overexpression of miR-22 in human or mouse mammary cells induces the upregulation of Zeb1/2, leading to a mesenchymal phenotype, expansion of the MaSCs, tumorigenesis, and metastasis [76]. Interestingly, miR-205 and miR-22 act as regulators of the EMT through regulation of the miR-200 family [76, 77], which are down regulated in normal MaSCs and breast cancer stem cells (BCSCs). Overexpression of miR-200c suppresses both clonogenicity of BCSCs and normal mammary outgrowth in vivo through targeting BMI1, a critical gene for selfrenewal in many types of stem cells [78].

Long noncoding RNAs are rising as remarkable mediators of many important processes, such as the regulators of stem/progenitor cell functions, and 
as modulators of gene expression through different mechanisms at both the transcriptional and posttranscriptional level. As much as $38 \%$ of lncRNAs have been given to cooperate with various chromatinmodifying complexes and $24 \%$ specifically interact with polycomb repressive complex2 (PRC2) [79]. H19, one of the earliest identified regulatory lncRNAs, might have an influence on mammary gland development. H19 is reported to be induced by estrogen and enriched in terminal end buds (TEBs) in pubertal mice and in the alveolar cells of pregnant mice [80]. In addition to restricting growth during embryonic development, recent data have reported that $\mathrm{H} 19$ ensures the maintenance of long-term hematopoietic stem cells [81]. Similarly, if H19 plays a part in the mammary gland, it might sustain stem and/or progenitor populations during highly proliferative pubertal and pregnant stages of mammary development [82]. Additionally, $\mathrm{H} 19$ is up regulated in breast cancer, suggesting an oncogenic role [83], although the mechanism is still poorly understood. The effects of other lncRNAs on MaSCs and mammary gland development are less well studied. Only SRA, Zfas1 (Znfx1 antisense 1), and mPINC (mouse pregnancy-induced non-coding RNA) have been observed to have a regulatory function in mammary development [84-87]. Thus, the roles of lncRNAs on MaSCs, mammary development, and tumorigenesis need to be further investigated.

\section{BREAST CANCER AND MASCS}

Breast cancer is a leading cause of death in women worldwide. Although breast cancer can be diagnosed early and better treatment has accompanied medical advances, its mortality rate remains high due to recurrence and metastasis [88]. Breast cancer is a heterogeneous disease. Heterogeneity of breast cancer is not only characterized by the same tumor type (intraheterogeneity), but also by diverse breast tumor subtypes (interheterogeneity) [89]. For interheterogeneity, breast cancer can be classified into different subtypes by histological and clinical factors. Eighteen different histological subtypes of breast cancer have been defined by the World Health Organization (WHO). In addition, molecular profiling also displays interheterogeneity of cancer [90]. These molecular profiling alterations will lead to the expression of oncogenes and the inhibition of tumor suppressor genes, which change the gene networks in normal mammary tissue. Based on molecular profiling alterations, breast cancer can be classified into five molecular subtypes, including luminal A, luminal B, HER2 positive (HER2 ${ }^{+}$), basal-like, and normal-like [91-93]. Luminal A breast cancer expresses both estrogen receptors $\left(\mathrm{ER}^{+}\right)$and/or progesterone receptors ( $\left.\mathrm{PR}^{+} / \mathrm{PR}^{-}\right)$, and is absent of HER2 expression. Luminal B is similar to luminal A, but with HER2 amplified. HER2 ${ }^{+}$breast cancer is characterized by HER2 expression and the absence of ER and PR. Basal- like subtypes negatively express ER, PR, and HER2. The gene expression signature of normal-like breast cancer is similar to that of normal mammary gland $[91,94,95]$. Different breast cancer subtypes show differences in survival rate, tumor incidence, and response to treatment. Positive outcomes have been observed in luminal tumors treated with hormonal therapy (tamoxifen). Because of high proliferation, HER2 ${ }^{+}$breast cancer always shows poorer outcomes, even when treated with HER2 antibodies such as trastuzumab [96]. Basal-like breast cancers are the most malignant cancers with poor patient outcomes and high levels of recurrence after treatment. Indeed, the complexity of this breast cancer is greater than that of previous subtypes. Recent research screened 2000 breast tumors and found a novel molecular classification of tumors, with ten diverse subtypes by combination of inherited and acquired genetic alterations [97]. For intraheterogeneity, breast cancer tissue includes different cell types and shows different morphological appearances at the histological level. This is mirrored by variable gene expression signatures in tumor tissues [98]. Currently, two different models show the origin of tumor heterogeneity: stem cell hierarchy and clonal evolution.

In the stem cell hierarchy model, cancer cells are considered to originate from cancer stem cells (CSCs) [99]. The theory of CSCs arises from the correlation between embryonic stem cell-induced teratocarcinomas and tumors [100]. Regarded as malignant stem cells, CSCs were first found in acute myeloid leukemia and are featured by stem cell-like characteristics, including self-renewal ability and differentiation potential [101]. CSCs divide into daughter cells that maintain the feature of self-renewal, while other daughter cells differentiate into neoplastic cells that form tumors. CSCs have been recognized in many kinds of solid tumor, including breast, prostate, brain, and lung cancer [102, 103]. BCSCs were the first to be reported in solid tumors. In breast cancer, tumors are hierarchically organized. The capability of self-renewal of BCSCs contributes to the growth, metastasis, and recurrence of breast tumor. In addition, the hierarchy model indicates that CSCs are derived from the transformation of normal stem cells, which means that a rare population of cells is more tumorigenic than a non-CSC population [102]. Although in vitro differentiation and in vivo xenograft data show that the human mammary gland is hierarchically organized, which supports the BCSC hypothesis [104], it is still elusive whether BCSCs derive from transformed progenitor cells, MaSCs, or both. Evidence from Al-Hajj et al. [105] proved the existence of BCSCs, and that a minority subpopulation of human breast cancer expressed the surface markers of $\mathrm{CD} 44^{+}$and $\mathrm{CD} 24^{- \text {low }}$ and could form heterogeneous tumors. Their ability to form tumors showed a 10 - to 50-fold increase compared with other tumor breast cancer cells [105]. However, the existence and origin of CSCs remain the subject of skepticism and intense debate. Some researchers believe that CSCs do not 
necessarily arise from the transformation of normal stem cells, and thus, they prefer to name these cells as 'cancerpropagating cells' or 'cancer-initiating cells'.

Currently, there are two hypotheses on the origin of BCSCs, that is, they arise either from MaSCs or from more differentiated and committed progenitor cells that acquire the ability of self-renewal via genetic and epigenetic reprogramming [96]. The mammary gland is a highly dynamic tissue. During pregnancy, MaSCs $\left(\mathrm{CD} 49 \mathrm{f}^{+} / \mathrm{CD} 29^{+} / \mathrm{CD} 24^{+}\right.$repopulating cells in a mouse model) are influenced by hormones and serve as a source of proliferation and differentiation for different mammary structural units and for developing a milk-generating breast $[8,9]$. As a result of the relatively long life span and ability of self-renewal, MaSCs have been advised as likely candidates for the initial malignant transforming events that drive cancer formation [106]. However, current clonal analyses and lineage-tracing experiments have identified that both luminal and myoepithelial progenitor cells are clonally expanding and maintain proliferation in adulthood [4], which means that these cells also are possible targets for tumor cellular transformation. Furthermore, other research has shown that luminal progenitor cells are a possible transformation target in basal-like breast cancers. Specifically, Lim et al. [59] firstly isolated and purified stem/progenitor cells (CD49f figh EpCAM $^{-}$; expressing p63/vimentin/CK14, but not ER/PR), luminal progenitor

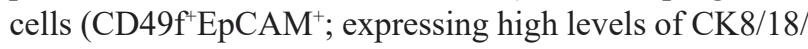
ER/GATA-3/MUC-1), and mature luminal cells (CD49f $\mathrm{EpCAM}^{+}$; expressing high levels of ER/PR) from normal mammary gland preneoplastic samples from volunteers who were heterozygous for BRCA1 mutation. BRCA1 mutations are clinically associated with the development of basal-like breast cancers [107]. The results of Lim et al. [59] showed that CD49f ${ }^{\text {high }}$ EpCAM- basal stem $^{-}$

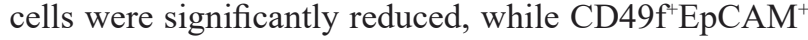
luminal progenitor cells were dramatically increased in the BRCA1-mutant samples. These observations, combined with succeeding gene expression profiling and functional studies, imply that a luminal progenitor population might be the transformation target in BRCA1-mutational basal breast tumors [59, 108]. Another mouse model of BRCA1-deficiency in either luminal progenitor cells or basal stem cells demonstrated that deletion of BRCA1 in the luminal progenitor cells, rather than the basal stem cells, phenotypically and histologically induced basal-like breast cancers [109]. In addition, it has been reported that luminal progenitor cells are the origin of TP53 mutated basal-like breast cancers [109, 110]. Although evidence supports that luminal progenitors are the cells-of-origin of basal-like breast cancers, there is no evidence showing that the malignant transformation of BCSCs does not originate from MaSCs. Actually, epidemiological studies have validated that an early and full-term pregnancy at a young age efficiently decreases the lifetime risk of breast cancer $[111,112]$. Depletion of MaSCs used for differentiation during pregnancy might be the reason why early pregnancy is protective against breast cancer. Two recent reports have indicated that significant expansion of MaSCs during pregnancy form many tumor features $[21,113]$, suggesting that expansion and transformation of MaSCs could induce the formation of these tumors. Thus, the precise cells-of-origin of BCSCs need to be well defined in further studies. The ability to better trace MaSC populations in vivo and directly proof their susceptibility to transformation in particular forms of breast cancer are essential.

Most data on the organization of the human mammary gland are inferred from a combination of results from in vitro assay, xenotransplantation, and flow cytometry. Human MaSCs were previously thought to show a $\mathrm{CD} 49 \mathrm{f}^{+} / \mathrm{ESA}^{-/ \text {low }}$ phenotype, implying a basal location in the mammary gland [59, 114]. Actually, the precise location and hierarchy of human MaSCs are still elusive. It remains undecided whether MaSCs differentiate into a common bipotent progenitor giving rise to directed progenitors [108]. Therefore, the possible cause for the currently undetermined cells-of-origin of BCSCs is the lack of specific markers for such lineages. Generally, existing data indicate that human BCSCs are enriched in $\mathrm{CD}_{4}{ }^{+} \mathrm{CD} 244^{-/ \text {low }}[105], \mathrm{PKH} 26$ [115], $\mathrm{ALDH}^{+}[16,116]$, and SP $[117,118]$ dye-retaining cells. BCSCs were first isolated by cell-surface markers (CD44 and ESA), and without CD24 [105]. Furthermore, $\mathrm{Lin}^{-} / \mathrm{ESA}^{+} / \mathrm{CD}^{4} 4^{+}$ $\mathrm{CD} 24^{-/ \text {low }} \mathrm{BCSCs}$ are reportedly more tumorigenic than $\mathrm{CD} 44^{+} / \mathrm{CD} 24^{+} / \mathrm{ESA}^{-}$cell populations. The molecular profiles of $\mathrm{CD}_{4} 4^{+}$and $\mathrm{CD} 24^{+}$cells show that $\mathrm{CD}_{4} 4^{+}$ cells express basal stem cell markers, while $\mathrm{CD} 24^{+}$cells express markers of differentiated luminal cell [119]. Nevertheless, only a small population of CD $44^{+} / \mathrm{CD} 24^{-/}$ low cells are highly tumorigenic, which suggests that these markers can be applied to isolate and enrich BCSCs, while they might be not a pure CSC population [120, 121]. ALDH1 is considered a good BCSC marker and an independent predictor of poor outcomes in breast cancer patients [122, 123]. ALDH1A1 is one of main isotypes of ALDH1. Ginestier et al. [16] reported that ALDH1A1 mRNA levels are positively correlated with poor clinical outcomes, and that $\mathrm{CD} 44^{+} / \mathrm{CD} 24^{-/ \text {low }} / \mathrm{ALDH} 1^{\text {high }} \mathrm{BCSCs}$ are more tumorigenic . Consistently, Morimoto et al. [124] also reported that ALDH1-positive breast cancers are more aggressive than other types of breast cancer. Charafe-Jauffret et al. [125] showed that ALDH1A1positive breast cancer cells promote tumor invasion and metastasis in mouse xenografts. Furthermore, recent metaanalysis has also indicated that ALDH1A1 can serve as a predictor of poor prognosis in breast cancer patients [126]. However, although ALDH1 appears to be a good independent biomarker for early metastasis and poor survival in breast cancer, debate still exists. For example, the expression of ALDH1 is low in normal MaSCs, but highly expressed in luminal progenitors, which raises the 
Table 1: Investigational agent targeting BCSCs in clinical development *

\begin{tabular}{|c|c|c|c|c|}
\hline $\begin{array}{l}\text { Compound and combination or } \\
\text { intervention }\end{array}$ & phase & Tumor type & $\begin{array}{l}\text { clinicaltrials.gov } \\
\text { identifier }\end{array}$ & status \\
\hline \multicolumn{5}{|l|}{ R04929097(GSI; Roche) } \\
\hline Plus vismodegib & I & $\begin{array}{l}\text { Breast cancer (HER2-, metastatic or } \\
\text { unresectable) }\end{array}$ & NCT01071564 & Terminated \\
\hline Plus letrozole & I & $\begin{array}{l}\text { Breast cancer (postmenopausal ER }+ \\
\text { stage II-III) }\end{array}$ & NCT01208441 & Terminated \\
\hline $\begin{array}{l}\text { Plus carboplatin and paclitaxel } \\
\text { before surgery }\end{array}$ & I & Stage II-III TNBC & NCT01238133 & Terminated \\
\hline Plus exemestane & $\mathrm{I} / \mathrm{II}$ & $\begin{array}{l}\text { Breast cancer (pre/postmenopausal, } \\
\text { advanced-stage or metastatic) }\end{array}$ & NCT01149356 & Terminated \\
\hline Single agent & II & $\begin{array}{l}\text { TNBC (advanced-stage, metastatic or } \\
\text { recurrent) }\end{array}$ & NCT01151449 & Terminated \\
\hline \multicolumn{5}{|l|}{ MK-0752 (GSI) } \\
\hline Plus Docetaxel & $\mathrm{I} / \mathrm{II}$ & Metastatic Breast Cancer & NCT00645333 & completed \\
\hline \multicolumn{5}{|l|}{ Vismodegib (Genentech) } \\
\hline With RO4929097 (Notch inhibitor) & I & Breast cancer & NCT01071564 & Terminated \\
\hline \multicolumn{5}{|c|}{ Sonidegib (aka erismodegib and LDE225; Novartis) } \\
\hline Single agent & $\begin{array}{l}\text { Randomized } \\
\text { II }\end{array}$ & $\begin{array}{l}\text { Breast cancer (stage II-III, } \\
\text { ER-, HER2-) }\end{array}$ & NCT01757327 & Withdrawn \\
\hline \multicolumn{5}{|c|}{ LGK-974 (Porcupine inhibitor; Novartis) } \\
\hline Single agent & I & breast neoplasms, TNBC & NCT01351103 & Suspended \\
\hline \multicolumn{5}{|c|}{ Vantictumab (aka OMP-18R5; anti-Frizzled-1/2/5/7/8 antibody; OncoMed/Cellgene) } \\
\hline With paclitaxel & I & Breast cancer & NCT01973309 & Recruiting \\
\hline \multicolumn{5}{|c|}{ CD105/Yb-1/SOX2/CDH3/MDM2-polyepitope Plasmid DNA Vaccine } \\
\hline Single agent & I & Breast cancer & NCT02157051 & Recruiting \\
\hline
\end{tabular}

* Data are from ClinicalTrials.gov as of Augest 20, 2016; GSI, $\gamma$-secretase inhibitor; ER, oestrogen receptor; TNBC; triplenegative breast cancer.

question of whether ALDH1 can truly identify BCSCs [127]. Thus, the significance of ALDH1 as a biomarker of BCSCs has yet to be completely elucidated.

Overlapping tumorigenic populations have been observed in BCSCs isolated and enriched by different approaches. For instance, although there is only a small overlap between $\mathrm{CD} 44^{+} \mathrm{CD} 24^{- \text {low }}$ and $\mathrm{ALDH}^{+}$cells,
$\mathrm{ALDH}^{+} \mathrm{CD} 44^{+}$cells seem to be more tumorigenic than cells that express one marker alone [16]. Although xenograft-initiating cells exist in both $\mathrm{CD}_{4} 4^{+} \mathrm{CD} 24$ and $\mathrm{CD}_{4} 4^{+} \mathrm{CD} 24^{+}$cell populations, BCSCs are more highly enriched using the combinatorial marker profile $\mathrm{CD} 4{ }^{+} \mathrm{CD} 49 \mathrm{f}^{\text {high }} \mathrm{CD} 133 / 2^{\text {high }}[128]$. 


\section{THERAPEUTIC TARGETING BCSCS \\ PERSPECTIVES}

Compared with common cancer cells, CSCs are slow-differential and have a lower ability to undergo apoptosis and a higher capability of DNA repair, making them more resistant to traditional chemotherapy and radiation cancer treatment [129]. Therefore, CSCs are regarded as the possible cause of therapy resistance and cancer recurrence. Although therapeutic methods targeting CSCs are widely studied and well-established, there is an alternative point of view in regards to such cells. Some researchers believe that proliferating cells, not CSCs, determine the progression, prognosis, resistance, and recurrence of advanced cancers that respond poorly to therapy [130]. Therapy-resistant clone cells, also known as cancer stemloids or stem cell-like cells, are proliferating, self-renewing cancer cells [131]. Therapeutic failure is often the result of the non-elimination of cancer stemloids. Therapy kills sensitive cells, resulting in the selection of resistant cells and the accumulation of stemness and resistance-conferring mutations $[130,131]$. Thus, cancer stemloids are considered to be crucial targets for cancer therapy.

Although the application of CSCs in cancer therapy remains a topic of debate, we have focused on the therapeutic perspectives targeting BCSCs in this review. Considerable evidence has shown that BCSCs are responsible for the initiation, maintenance, metastasis, and recurrence of cancer, as well as resistance to traditional cancer treatment [129]. Recent reports using single-cell analysis have suggested that stem-like breast cancer cells initiate and propagate metastatic tumors [132]. Thus, targeting BCSCs is considered good clinical practice in the treatment of breast cancer, and can be achieved by a number of approaches, including chemotherapy sensitization of BCSCs, differentiating therapy, stem cell elimination, and suppression of regulatory pathways involved in self-renewal. For enhancement of chemotherapy sensitization, several pathways have been involved in sensitizing BCSCs, including increasing efflux of chemotherapeutic agents by the upregulation of cell-surface transporters of the ATP-binding cassette (ABC) family, increasing sensitivity to apoptosis though the alterations in the expression of Bcl 2 family members, and reducing topoisomerase II expression [133, 134]. For targeting stem cell elimination, tumor formation is also driven by the expression of some genes involved in "stemness", including Oct4, Nanog, and Sox2 [135]. Reversal of the expression of these genes might be a novel way to target BCSCs [129]. As BCSCs are often quiescent, they are also often resistant to traditional treatment. Differentiated BCSCs are easier to eliminate by differentiating therapy, which suggests that small molecules such as retinoic acid and other vitamin A analogues [136] can be used for breast cancer therapy treatment by differentiation induction. The Retinal Determination Gene Network (RDGN) is a regulatory network that is dysregulated in cancer [137, 138]. Key RDGN members, including DACH, EYA, and SIX, are potential therapeutic targets. In breast cancer, EYA raises tumor growth and increases the ratio of BCSCs [139]. SIX is enriched in the $\mathrm{CD} 44^{+} \mathrm{CD} 24^{- \text {llow }}$ subpopulation [140], whereas DACH might act as a tumor suppressor to reduce the number of BCSC subpopulations in vitro and in vivo though phosphorylating GSK3 $\beta$ and inhibiting Wnt signaling, compliance with findings in colorectal carcinomas [141, 142]. In this respect, research has also shown that the decreasing of DACH1 is tightly correlated with poor prognosis in basal-like breast cancer, suggesting the role of DACH1 as a potential predictor of survival in breast cancer patients [143, 144].

For suppression of regulatory pathways involved in self-renewal, the famous Notch, Hh, and Wnt signaling pathways have essential roles in the self-renewal of CSC populations. Here, we introduce some agents targeting these pathways and BCSCs in clinical trials (Table 1). Notch signaling influences self-renewal and lineagespecific differentiation of MaSCs [145], with Notch4 activity up regulated in BCSCs. Therefore, inhibition of Notch4 activity can decrease the BCSC population, and suppress tumor initiation [146]. The $\gamma$-secretase inhibitors (GSIs), targeting the Notch pathway, can inhibit the final proteolytic cleavage of Notch receptors, and result in suppression of the release of active intracellular fragments [147]. GSIs were the first Notch inhibitor developed for clinical cancer treatment [147], and exhibit anti-CSC activity in ex vivo patient-derived tumor specimens and breast-cancer-derived secondary mammospheres [148-151]. Notch pathway inhibitors combined with chemotherapy or other targeted agents exhibit strong antitumor activity. For HER2 positive subtype, GSIs together with trastuzumab completely cure and abrogate recurrence of tumor in mice [152]. In addition, optimal efficacy has been observed when Notch pathway inhibitors are combined with HER2 inhibitors in HER2-positive breast cancer $[152,153]$, with endocrine therapy in ER-positive breast cancer [154], and with taxanes and MET inhibitors in triple-negative breast cancer $[155,156]$.

The Wnt signaling pathway is important for the regulation and sustain of CSC properties. Abnormal Wnt/ $\beta$-catenin signaling has also been reported in breast cancer $[29,33]$. So far, several kinds of Wnt-signaling inhibitors have been developed for use in anti-cancer therapies. The LGK-974 drug, which inhibits porcupine and thereby decreases the secretion of Wnt proteins, is being tested in phase I trials in Wnt-ligand-dependent tumors, including breast cancer, melanoma, and pancreatic cancer [147]. Abnormal regulation of the Hh pathway is associated with many human malignancies. Several agents targeting the Hh pathway have been investigated in phase I and II clinical trials [157]. In addition, dysregulation of the $\mathrm{Hh}$ 
pathway is also reportedly involved in breast malignancies [158]. Of note, the PI3K/Akt pathway, which suppresses GSK $3 \beta$, can concurrently activate the Wnt/ $\beta$-catenin and $\mathrm{Hh}$ pathways [159]. In tamoxifen-resistant breast cancer cells, a suppressor of the PI3K/Akt pathway has been found to block both Hh and Wnt signaling, thereby showing better anti-tumor activity [159].

\section{GRANT SUPPORT}

This study was supported by the National Key Research and Development Program of China (No. 2016YFA0100903), Strategic Priority Research Program of the Chinese Academy of Sciences (No. XDB13030400), National Science Foundation of China (No. 31371502), and CAS "Light of West China" Program to H.W.

\section{CONFLICTS OF INTEREST}

The authors declare no conflicts of interest.

\section{REFERENCES}

1. Kessenbrock K, Dijkgraaf GJ, Lawson DA, Littlepage LE, Shahi P, Pieper U and Werb Z. A role for matrix metalloproteinases in regulating mammary stem cell function via the Wnt signaling pathway. Cell stem cell. 2013; 13(3):300-313.

2. Inman JL, Robertson C, Mott JD and Bissell MJ. Mammary gland development: cell fate specification, stem cells and the microenvironment. Development. 2015; 142(6):10281042 .

3. Fata JE, Chaudhary V and Khokha R. Cellular turnover in the mammary gland is correlated with systemic levels of progesterone and not 17 beta-estradiol during the estrous cycle. Biol Reprod. 2001; 65(3):680-688.

4. Van Keymeulen A, Rocha AS, Ousset M, Beck B, Bouvencourt G, Rock J, Sharma N, Dekoninck S and Blanpain C. Distinct stem cells contribute to mammary gland development and maintenance. Nature. 2011; 479(7372):189-193.

5. Kessenbrock K, Plaks V and Werb Z. Matrix metalloproteinases: regulators of the tumor microenvironment. Cell. 2010; 141(1):52-67.

6. Page-McCaw A, Ewald AJ and Werb Z. Matrix metalloproteinases and the regulation of tissue remodelling. Nature reviews Molecular cell biology. 2007; 8(3):221-233.

7. Kouros-Mehr $\mathrm{H}$ and Werb Z. Candidate regulators of mammary branching morphogenesis identified by genomewide transcript analysis. Developmental dynamics. 2006; 235(12):3404-3412.

8. Stingl J, Eirew P, Ricketson I, Shackleton M, Vaillant F, Choi D, Li HI and Eaves CJ. Purification and unique properties of mammary epithelial stem cells. Nature. 2006;
439(7079):993-997.

9. Shackleton M, Vaillant F, Simpson KJ, Stingl J, Smyth GK, Asselin-Labat ML, Wu L, Lindeman GJ and Visvader JE. Generation of a functional mammary gland from a single stem cell. Nature. 2006; 439(7072):84-88.

10. Reya T, Morrison SJ, Clarke MF and Weissman IL. Stem cells, cancer, and cancer stem cells. Nature. 2001; 414(6859):105-111.

11. Keller PJ, Arendt LM and Kuperwasser C. Stem cell maintenance of the mammary gland: it takes two. Cell stem cell. 2011; 9(6):496-497.

12. dos Santos CO, Rebbeck C, Rozhkova E, Valentine A, Samuels A, Kadiri LR, Osten P, Harris EY, Uren PJ, Smith AD and Hannon GJ. Molecular hierarchy of mammary differentiation yields refined markers of mammary stem cells. Proceedings of the National Academy of Sciences of the United States of America. 2013; 110(18):7123-7130.

13. Welm BE, Tepera SB, Venezia T, Graubert TA, Rosen JM and Goodell MA. Sca-1(pos) cells in the mouse mammary gland represent an enriched progenitor cell population. Developmental biology. 2002; 245(1):42-56.

14. Jones PH, Harper S and Watt FM. Stem cell patterning and fate in human epidermis. Cell. 1995; 80(1):83-93.

15. Rietze RL, Valcanis H, Brooker GF, Thomas T, Voss AK and Bartlett PF. Purification of a pluripotent neural stem cell from the adult mouse brain. Nature. 2001; 412(6848):736739.

16. Ginestier C, Hur MH, Charafe-Jauffret E, Monville F, Dutcher J, Brown M, Jacquemier J, Viens P, Kleer CG, Liu S, Schott A, Hayes D, Birnbaum D, et al. ALDH1 is a marker of normal and malignant human mammary stem cells and a predictor of poor clinical outcome. Cell stem cell. 2007; 1(5):555-567.

17. Ibarra I, Erlich Y, Muthuswamy SK, Sachidanandam R and Hannon GJ. A role for microRNAs in maintenance of mouse mammary epithelial progenitor cells. Genes \& development. 2007; 21(24):3238-3243.

18. Wang D, Cai C, Dong X, Yu QC, Zhang XO, Yang L and Zeng YA. Identification of multipotent mammary stem cells by protein $\mathrm{C}$ receptor expression. Nature. 2015; 517(7532):81-84.

19. Blanpain $\mathrm{C}$ and Fuchs E. Epidermal homeostasis: a balancing act of stem cells in the skin. Nat Rev Mol Cell Bio. 2009; 10(3):207-U267.

20. Visvader JE. Keeping abreast of the mammary epithelial hierarchy and breast tumorigenesis. Genes \& development. 2009; 23(22):2563-2577.

21. Asselin-Labat ML, Vaillant F, Sheridan JM, Pal B, Wu D, Simpson ER, Yasuda H, Smyth GK, Martin TJ, Lindeman GJ and Visvader JE. Control of mammary stem cell function by steroid hormone signalling. Nature. 2010; 465(7299):798-802.

22. Rios AC, Fu NY, Lindeman GJ and Visvader JE. In situ identification of bipotent stem cells in the mammary gland. 
Nature. 2014; 506(7488):322-+.

23. Cadigan KM and Nusse R. Wnt signaling: a common theme in animal development. Genes \& development. 1997; 11(24):3286-3305.

24. Polakis P. Wnt signaling and cancer. Genes \& development. 2000; 14(15):1837-1851.

25. Miller JR. The Wnts. Genome biology. 2002; 3(1):REVIEWS3001.

26. Brennan KR and Brown AM. Wnt proteins in mammary development and cancer. Journal of mammary gland biology and neoplasia. 2004; 9(2):119-131.

27. Robinson GW, Hennighausen L and Johnson PF. Sidebranching in the mammary gland: the progesterone-Wnt connection. Genes \& development. 2000; 14(8):889-894.

28. Hsu W, Shakya R and Costantini F. Impaired mammary gland and lymphoid development caused by inducible expression of Axin in transgenic mice. The Journal of cell biology. 2001; 155(6):1055-1064.

29. Zeng YA and Nusse R. Wnt Proteins Are Self-Renewal Factors for Mammary Stem Cells and Promote Their LongTerm Expansion in Culture. Cell stem cell. 2010; 6(6):568577.

30. Lustig B, Jerchow B, Sachs M, Weiler S, Pietsch T, Karsten U, van de Wetering M, Clevers H, Schlag PM, Birchmeier W and Behrens J. Negative feedback loop of Wnt signaling through upregulation of conductin/Axin2 in colorectal and liver tumors. Mol Cell Biol. 2002; 22(4):1184-1193.

31. Tepera SB, McCrea PD and Rosen JM. A beta-catenin survival signal is required for normal lobular development in the mammary gland. J Cell Sci. 2003; 116(6):1137-1149.

32. Wang XY, Yin Y, Yuan H, Sakamaki T, Okano H and Glazer RI. Musashil modulates mammary progenitor cell expansion through proliferin-mediated activation of the Wnt and Notch pathways. Mol Cell Biol. 2008; 28(11):35893599 .

33. Malanchi I, Peinado H, Kassen D, Hussenet T, Metzger D, Chambon P, Huber M, Hohl D, Cano A, Birchmeier W and Huelsken J. Cutaneous cancer stem cell maintenance is dependent on beta-catenin signalling. Nature. 2008; 452(7187):650-U612.

34. Callahan R and Egan SE. Notch signaling in mammary development and oncogenesis. Journal of mammary gland biology and neoplasia. 2004; 9(2):145-163.

35. Bray SJ. Notch signalling: a simple pathway becomes complex. Nature reviews Molecular cell biology. 2006; 7(9):678-689.

36. Kopan R. Notch signaling. Cold Spring Harbor perspectives in biology. 2012; 4(10).

37. Kopan R and Ilagan MX. The canonical Notch signaling pathway: unfolding the activation mechanism. Cell. 2009; 137(2):216-233.

38. Hori K, Sen A and Artavanis-Tsakonas S. Notch signaling at a glance. J Cell Sci. 2013; 126(10):2135-2140.
39. Rodilla V, Dasti A, Huyghe M, Lafkas D, Laurent C, Reyal F and Fre S. Luminal Progenitors Restrict Their Lineage Potential during Mammary Gland Development. Plos Biol. $2015 ; 13(2)$.

40. Turner N, Lambros MB, Horlings HM, Pearson A, Sharpe R, Natrajan R, Geyer FC, van Kouwenhove M, Kreike B, Mackay A, Ashworth A, de Vijver MJV and Reis-Filho JS. Integrative molecular profiling of triple negative breast cancers identifies amplicon drivers and potential therapeutic targets. Oncogene. 2010; 29(14):2013-2023.

41. Alunni A, Krecsmarik M, Bosco A, Galant S, Pan LY, Moens CB and Bally-Cuif L. Notch3 signaling gates cell cycle entry and limits neural stem cell amplification in the adult pallium. Development. 2013; 140(16):3335-3347.

42. Kitamoto $\mathrm{T}$ and Hanaoka K. Notch3 Null Mutation in Mice Causes Muscle Hyperplasia by Repetitive Muscle Regeneration. Stem Cells. 2010; 28(12):2205-2216.

43. Kent S, Hutchinson J, Balboni A, DeCastro A, Cherukuri $\mathrm{P}$ and DiRenzo J. Delta Np63 alpha promotes cellular quiescence via induction and activation of Notch3. Cell Cycle. 2011; 10(18).

44. Lafkas D, Rodilla V, Huyghe M, Mourao L, Kiaris H and Fre S. Notch3 marks clonogenic mammary luminal progenitor cells in vivo. Journal of Cell Biology. 2013; 203(1):47-56.

45. Bouras T, Pal B, Vaillant F, Harburg G, Asselin-Labat ML, Oakes SR, Lindeman GJ and Visvader JE. Notch Signaling Regulates Mammary Stem Cell Function and Luminal CellFate Commitment. Cell stem cell. 2008; 3(4):429-441.

46. Nussleinvolhard C and Wieschaus E. Mutations Affecting Segment Number and Polarity in Drosophila. Nature. 1980; 287(5785):795-801.

47. Lewis MT. Hedgehog signaling in mouse mammary gland development and neoplasia. Journal of mammary gland biology and neoplasia. 2001; 6(1):53-66.

48. Kasper M, Regi G, Frischauf AM and Aberger F. GLI transcription factors: Mediators of oncogenic Hedgehog signalling. Eur J Cancer. 2006; 42(4):437-445.

49. Lewis MT and Visbal AP. The hedgehog signaling network, mammary stem cells, and breast cancer: Connections and controversies. Ernst Schering Found. 2007; 5:181-217.

50. Fiaschi M, Rozell B, Bergstrom A and Toftgard R. Development of mammary tumors by conditional expression of GLI1. Cancer Res. 2009; 69(11):4810-4817.

51. Liu SL, Dontu G, Mantle ID, Patel S, Ahn NS, Jackson KW, Suri P and Wicha MS. Hedgehog signaling and Bmi1 regulate self-renewal of normal and malignant human mammary stem cells. Cancer Res. 2006; 66(12):6063-6071.

52. Pietersen AM, Evers B, Prasad AA, Tanger E, CornelissenSteijger P, Jonkers J and van Lohuizen M. Bmil regulates stem cells and proliferation and differentiation of committed cells in mammary epithelium. Curr Biol. 2008; 18(14):1094-1099.

53. Yamaji D, Na RS, Feuermann Y, Pechhold S, Chen WP, 
Robinson GW and Hennighausen L. Development of mammary luminal progenitor cells is controlled by the transcription factor STAT5A. Genes \& development. 2009; 23(20):2382-2387.

54. Siegel PM and Muller WJ. Transcription factor regulatory networks in mammary epithelial development and tumorigenesis. Oncogene. 2010; 29(19):2753-2759.

55. Spike BT and Wahl GM. p53, Stem Cells, and Reprogramming: Tumor Suppression beyond Guarding the Genome. Genes Cancer. 2011; 2:404-19. doi: 10.1177/1947601911410224.

56. Bonizzi G, Cicalese A, Insinga A and Pelicci PG. The emerging role of p53 in stem cells. Trends Mol Med. 2012; 18(1):6-12.

57. Chiche A, Moumen M, Petit V, Jonkers J, Medina D, Deugnier MA, Faraldo MM and Glukhova MA. Somatic Loss of p53 Leads to Stem/progenitor Cell Amplification in Both Mammary Epithelial Compartments, Basal and Luminal. Stem Cells. 2013; 31(9):1857-1867.

58. Joshi PA, Jackson HW, Beristain AG, Di Grappa MA, Mote PA, Clarke CL, Stingl J, Waterhouse PD and Khokha R. Progesterone induces adult mammary stem cell expansion. Nature. 2010; 465(7299):803-807.

59. Lim E, Vaillant F, Wu D, Forrest NC, Pal B, Hart AH, Asselin-Labat ML, Gyorki DE, Ward T, Partanen A, Feleppa F, Huschtscha LI, Thorne HJ, et al. Aberrant luminal progenitors as the candidate target population for basal tumor development in BRCA1 mutation carriers. Nat Med. 2009; 15(8):907-913.

60. Lombardi S, Honeth G, Ginestier C, Shinomiya I, Marlow R, Buchupalli B, Gazinska P, Brown J, Catchpole S, Liu SL, Barkan A, Wicha M, Purushotham A, et al. Growth Hormone Is Secreted by Normal Breast Epithelium upon Progesterone Stimulation and Increases Proliferation of Stem/Progenitor Cells. Stem Cell Rep. 2014; 2(6):780-793.

61. Pellegrini P, Cordero A, Gallego MI, Dougall WC, Purificacion M, Pujana MA and Gonzalez-Suarez E. Constitutive Activation of RANK Disrupts Mammary Cell Fate Leading to Tumorigenesis (vol 31, pg 1954, 2013). Stem Cells. 2014; 32(2):600-600.

62. Beleut M, Rajaram RD, Caikovski M, Ayyanan A, Germano D, Choi Y, Schneider P and Brisken C. Two distinct mechanisms underlie progesterone-induced proliferation in the mammary gland. Proceedings of the National Academy of Sciences of the United States of America. 2010; 107(7):2989-2994.

63. de Lau W, Peng WC, Gros P and Clevers H. The R-spondin/ Lgr5/Rnf43 module: regulator of Wnt signal strength. Genes \& development. 2014; 28(4):305-316.

64. Joshi PA, Waterhouse PD, Kannan N, Narala S, Fang H, Di Grappa MA, Jackson HW, Penninger JM, Eaves C and Khokha R. RANK Signaling Amplifies WNT-Responsive Mammary Progenitors through R-SPONDIN1. Stem Cell Rep. 2015; 5(1):31-44.
65. Cai CG, Yu QC, Jiang WM, Liu W, Song WQ, Yu H, Zhang L, Yang Y and Zeng YA. R-spondin1 is a novel hormone mediator for mammary stem cell self-renewal. Genes \& development. 2014; 28(20):2205-2218.

66. Forsman CL, Ng BC, Heinze RK, Kuo C, Sergi C, Gopalakrishnan R, Yee D, Graf D, Schwertfeger KL and Petryk A. BMP-binding protein twisted gastrulation is required in mammary gland epithelium for normal ductal elongation and myoepithelial compartmentalization. Developmental biology. 2013; 373(1):95-106.

67. Chapellier M, Bachelard-Cascales E, Schmidt X, Clement F, Treilleux I, Delay E, Jammot A, Menetrier-Caux C, Pochon G, Besancon R, Voeltzel T, Caron de Fromentel C, Caux C, et al. Disequilibrium of BMP2 levels in the breast stem cell niche launches epithelial transformation by overamplifying BMPR1B cell response. Stem Cell Rep. 2015; 4(2):239-254.

68. Booth BW, Boulanger CA and Smith GH. Stem cells and the mammary microenvironment. Breast disease. 2008; 29:57-67.

69. LaBarge MA, Nelson CM, Villadsen R, Fridriksdottir A, Ruth JR, Stampfer MR, Petersen OW and Bissell MJ. Human mammary progenitor cell fate decisions are products of interactions with combinatorial microenvironments. Integrative biology. 2009; 1(1):70-79.

70. Tordonato C, Di Fiore PP and Nicassio F. The role of noncoding RNAs in the regulation of stem cells and progenitors in the normal mammary gland and in breast tumors. Frontiers in genetics. 2015; 6:72.

71. Elsarraj HS, Hong Y, Valdez K, Carletti M, Salah SM, Raimo M, Taverna D, Prochasson P, Bharadwaj U, Tweardy DJ, Christenson LK and Behbod F. A novel role of microRNA146b in promoting mammary alveolar progenitor cell maintenance. J Cell Sci. 2013; 126(11):2446-2458.

72. Bockmeyer CL, Christgen M, Muller M, Fischer S, Ahrens P, Langer F, Kreipe H and Lehmann U. MicroRNA profiles of healthy basal and luminal mammary epithelial cells are distinct and reflected in different breast cancer subtypes. Breast Cancer Res Tr. 2011; 130(3):735-745.

73. Elsarraj HS, Stecklein SR, Valdez K and Behbod F. Emerging Functions of microRNA-146a/b in Development and Breast Cancer MicroRNA-146a/b in Development and Breast Cancer. Journal of mammary gland biology and neoplasia. 2012; 17(1):79-87.

74. Yoo KH, Kang K, Feuermann Y, Jang SJ, Robinson GW and Hennighausen L. The STAT5-regulated miR-193b locus restrains mammary stem and progenitor cell activity and alveolar differentiation. Developmental biology. 2014; 395(2):245-254.

75. Chao CH, Chang CC, Wu MJ, Ko HW, Wang D, Hung MC, Yang JY and Chang CJ. MicroRNA-205 signaling regulates mammary stem cell fate and tumorigenesis. J Clin Invest. 2014; 124(7):3093-3106.

76. Song SJ, Poliseno L, Song MS, Ala U, Webster K, Ng C, 
Beringer G, Brikbak NJ, Yuan X, Cantley LC, Richardson AL and Pandolfi PP. MicroRNA-Antagonism Regulates Breast Cancer Stemness and Metastasis via TET-FamilyDependent Chromatin Remodeling. Cell. 2013; 154(2):311324.

77. Gregory PA, Bert AG, Paterson EL, Barry SC, Tsykin A, Farshid G, Vadas MA, Khew-Goodall Y and Goodall GJ. The mir-200 family and mir-205 regulate epithelial to mesenchymal transition by targeting ZEB1 and SIP1. Nat Cell Biol. 2008; 10(5):593-601.

78. Shimono Y, Zabala M, Cho RW, Lobo N, Dalerba P, Qian DL, Diehn M, Liu HP, Panula SP, Chiao E, Dirbas FM, Somlo G, Pera RAR, et al. Downregulation of miRNA-200c Links Breast Cancer Stem Cells with Normal Stem Cells. Cell. 2009; 138(3):592-603.

79. Khalil AM, Guttman M, Huarte M, Garber M, Raj A, Morales DR, Thomas K, Presser A, Bernstein BE, van Oudenaarden A, Regev A, Lander ES and Rinn JL. Many human large intergenic noncoding RNAs associate with chromatin-modifying complexes and affect gene expression. Proceedings of the National Academy of Sciences of the United States of America. 2009; 106(28):11667-11672.

80. Adriaenssens E, Lottin S, Dugimont T, Fauquette W, Coll J, Dupouy JP, Boilly B and Curgy JJ. Steroid hormones modulate $\mathrm{H} 19$ gene expression in both mammary gland and uterus. Oncogene. 1999; 18(31):4460-4473.

81. Venkatraman A, He XC, Thorvaldsen JL, Sugimura R, Perry JM, Tao F, Zhao M, Christenson MK, Sanchez R, Yu JY, Peng L, Haug JS, Paulson A, et al. Maternal imprinting at the H19-Igf2 locus maintains adult haematopoietic stem cell quiescence. Nature. 2013; 500(7462):345-349.

82. Shore AN and Rosen JM. Regulation of mammary epithelial cell homeostasis by lncRNAs. Int J Biochem Cell B. 2014; 54:318-330.

83. Adriaenssens E, Dumont L, Lottin S, Bolle D, Lepretre A, Delobelle A, Bouali F, Dugimont T, Coll J and Curgy JJ. H19 overexpression in breast adenocarcinoma stromal cells is associated with tumor values and steroid receptor status but independent of p53 and Ki-67 expression. Am J Pathol. 1998; 153(5):1597-1607.

84. Lanz RB, Chua SS, Barron N, Soder BM, DeMayo F and O'Malley BW. Steroid receptor RNA activator stimulates proliferation as well as apoptosis in vivo. Mol Cell Biol. 2003; 23(20):7163-7176.

85. Askarian-Amiri ME, Crawford J, French JD, Smart CE, Smith MA, Clark MB, Ru KL, Mercer TR, Thompson ER, Lakhani SR, Vargas AC, Campbell IG, Brown MA, et al. SNORD-host RNA Zfas 1 is a regulator of mammary development and a potential marker for breast cancer. Rna. 2011; 17(5):878-891.

86. Ginger MR, Gonzalez-Rimbau MF, Gay JP and Rosen JM. Persistent changes in gene expression induced by estrogen and progesterone in the rat mammary gland. Mol Endocrinol. 2001; 15(11):1993-2009.
87. Ginger MR, Shore AN, Contreras A, Rijnkels M, Miller J, Gonzalez-Rimbau MF and Rosen JM. A noncoding RNA is a potential marker of cell fate during mammary gland development. Proceedings of the National Academy of Sciences of the United States of America. 2006; 103(15):5781-5786.

88. Jemal A, Bray F, Center MM, Ferlay J, Ward E and Forman D. Global cancer statistics. CA Cancer J Clin. 2011; 61(2):69-90.

89. Almendro V and Fuster G. Heterogeneity of breast cancer: etiology and clinical relevance. Clin Transl Oncol. 2011; 13(11):767-773.

90. Reis-Filho JS and Pusztai L. Gene expression profiling in breast cancer: classification, prognostication, and prediction. Lancet. 2011; 378(9805):1812-1823.

91. Sorlie T, Perou CM, Tibshirani R, Aas T, Geisler S, Johnsen H, Hastie T, Eisen MB, van de Rijn M, Jeffrey SS, Thorsen T, Quist H, Matese JC, et al. Gene expression patterns of breast carcinomas distinguish tumor subclasses with clinical implications. Proc Natl Acad Sci U S A. 2001; 98(19):10869-10874.

92. Sorlie T, Tibshirani R, Parker J, Hastie T, Marron JS, Nobel A, Deng S, Johnsen H, Pesich R, Geisler S, Demeter J, Perou CM, Lonning PE, et al. Repeated observation of breast tumor subtypes in independent gene expression data sets. Proc Natl Acad Sci U S A. 2003; 100(14):8418-8423.

93. Sotiriou C, Neo SY, McShane LM, Korn EL, Long PM, Jazaeri A, Martiat P, Fox SB, Harris AL and Liu ET. Breast cancer classification and prognosis based on gene expression profiles from a population-based study. Proc Natl Acad Sci U S A. 2003; 100(18):10393-10398.

94. Perou CM, Sorlie T, Eisen MB, van de Rijn M, Jeffrey SS, Rees CA, Pollack JR, Ross DT, Johnsen H, Akslen LA, Fluge O, Pergamenschikov A, Williams C, et al. Molecular portraits of human breast tumours. Nature. 2000; 406(6797):747-752.

95. Calza S, Hall P, Auer G, Bjohle J, Klaar S, Kronenwett U, Liu ET, Miller L, Ploner A, Smeds J, Bergh J and Pawitan Y. Intrinsic molecular signature of breast cancer in a population-based cohort of 412 patients. Breast Cancer Res. 2006; 8(4):R34.

96. Shah $M$ and Allegrucci C. Keeping an open mind: highlights and controversies of the breast cancer stem cell theory. Breast Cancer (Dove Med Press). 2012; 4:155-166.

97. Curtis C, Shah SP, Chin SF, Turashvili G, Rueda OM, Dunning MJ, Speed D, Lynch AG, Samarajiwa S, Yuan Y, Graf S, Ha G, Haffari G, et al. The genomic and transcriptomic architecture of 2,000 breast tumours reveals novel subgroups. Nature. 2012; 486(7403):346-352.

98. Allred DC, Brown P and Medina D. The origins of estrogen receptor alpha-positive and estrogen receptor alpha-negative human breast cancer. Breast Cancer Res. 2004; 6(6):240245.

99. Shackleton M, Quintana E, Fearon ER and Morrison SJ. 
Heterogeneity in cancer: cancer stem cells versus clonal evolution. Cell. 2009; 138(5):822-829.

100. Shah $M$ and Allegrucci C. Stem cell plasticity in development and cancer: epigenetic origin of cancer stem cells. Subcell Biochem. 2013; 61:545-565.

101. Pardal R, Clarke MF and Morrison SJ. Applying the principles of stem-cell biology to cancer. Nat Rev Cancer. 2003; 3(12):895-902.

102. Visvader JE and Lindeman GJ. Cancer stem cells in solid tumours: accumulating evidence and unresolved questions. Nat Rev Cancer. 2008; 8(10):755-768.

103. Pattabiraman DR and Weinberg RA. Tackling the cancer stem cells - what challenges do they pose? Nat Rev Drug Discov. 2014; 13(7):497-512.

104. Visvader JE. Cells of origin in cancer. Nature. 2011; 469(7330):314-322.

105. Al-Hajj M, Wicha MS, Benito-Hernandez A, Morrison SJ and Clarke MF. Prospective identification of tumorigenic breast cancer cells. Proc Natl Acad Sci U S A. 2003; 100(7):3983-3988.

106. Tiede B and Kang Y. From milk to malignancy: the role of mammary stem cells in development, pregnancy and breast cancer. Cell Res. 2011; 21(2):245-257.

107. Turner NC and Reis-Filho JS. Basal-like breast cancer and the BRCA1 phenotype. Oncogene. 2006; 25(43):58465853.

108. Raouf A, Sun Y, Chatterjee S and Basak P. The biology of human breast epithelial progenitors. Seminars in cell \& developmental biology. 2012; 23(5):606-612.

109. Molyneux G, Geyer FC, Magnay FA, McCarthy A, Kendrick H, Natrajan R, Mackay A, Grigoriadis A, Tutt A, Ashworth A, Reis-Filho JS and Smalley MJ. BRCA1 basal-like breast cancers originate from luminal epithelial progenitors and not from basal stem cells. Cell Stem Cell. 2010; 7(3):403-417.

110. Proia TA, Keller PJ, Gupta PB, Klebba I, Jones AD, Sedic M, Gilmore H, Tung N, Naber SP, Schnitt S, Lander ES and Kuperwasser C. Genetic predisposition directs breast cancer phenotype by dictating progenitor cell fate. Cell Stem Cell. 2011; 8(2):149-163.

111. Britt K, Ashworth A and Smalley M. Pregnancy and the risk of breast cancer. Endocr Relat Cancer. 2007; 14(4):907933.

112. Russo J, Moral R, Balogh GA, Mailo D and Russo IH. The protective role of pregnancy in breast cancer. Breast Cancer Res. 2005; 7(3):131-142.

113. Tiede BJ, Owens LA, Li F, DeCoste C and Kang Y. A novel mouse model for non-invasive single marker tracking of mammary stem cells in vivo reveals stem cell dynamics throughout pregnancy. PLoS One. 2009; 4(11):e8035.

114. Eirew P, Stingl J, Raouf A, Turashvili G, Aparicio S, Emerman JT and Eaves CJ. A method for quantifying normal human mammary epithelial stem cells with in vivo regenerative ability. Nat Med. 2008; 14(12):1384-1389.

115. Pece S, Tosoni D, Confalonieri S, Mazzarol G, Vecchi M, Ronzoni S, Bernard L, Viale G, Pelicci PG and Di Fiore PP. Biological and molecular heterogeneity of breast cancers correlates with their cancer stem cell content. Cell. 2010; 140(1):62-73.

116. Charafe-Jauffret E, Ginestier C, Iovino F, Wicinski J, Cervera N, Finetti P, Hur MH, Diebel ME, Monville F, Dutcher J, Brown M, Viens P, Xerri L, et al. Breast cancer cell lines contain functional cancer stem cells with metastatic capacity and a distinct molecular signature. Cancer Res. 2009; 69(4):1302-1313.

117. Hirschmann-Jax C, Foster AE, Wulf GG, Nuchtern JG, Jax TW, Gobel U, Goodell MA and Brenner MK. A distinct "side population" of cells with high drug efflux capacity in human tumor cells. Proc Natl Acad Sci U S A. 2004; 101(39):14228-14233.

118. Engelmann K, Shen H and Finn OJ. MCF7 side population cells with characteristics of cancer stem/progenitor cells express the tumor antigen MUC1. Cancer Res. 2008; 68(7):2419-2426.

119. Shipitsin M, Campbell LL, Argani P, Weremowicz S, Bloushtain-Qimron N, Yao J, Nikolskaya T, Serebryiskaya T, Beroukhim R, Hu M, Halushka MK, Sukumar S, Parker LM, et al. Molecular definition of breast tumor heterogeneity. Cancer Cell. 2007; 11(3):259-273.

120. Ponti D, Costa A, Zaffaroni N, Pratesi G, Petrangolini G, Coradini D, Pilotti S, Pierotti MA and Daidone MG. Isolation and in vitro propagation of tumorigenic breast cancer cells with stem/progenitor cell properties. Cancer Res. 2005; 65(13):5506-5511.

121. Fillmore CM and Kuperwasser C. Human breast cancer cell lines contain stem-like cells that self-renew, give rise to phenotypically diverse progeny and survive chemotherapy. Breast Cancer Res. 2008; 10(2):R25.

122. Tomita H, Tanaka K, Tanaka T and Hara A. Aldehyde dehydrogenase 1A1 in stem cells and cancer. Oncotarget. 2016; 7:11018-11032. doi: 10.18632/oncotarget.6920.

123. Dong Y, Bi LR, Xu N, Yang HM, Zhang HT, Ding Y, Shi AP and Fan ZM. The expression of aldehyde dehydrogenase 1 in invasive primary breast tumors and axillary lymph node metastases is associated with poor clinical prognosis. Pathol Res Pract. 2013; 209(9):555-561.

124. Morimoto K, Kim SJ, Tanei T, Shimazu K, Tanji Y, Taguchi T, Tamaki Y, Terada N and Noguchi S. Stem cell marker aldehyde dehydrogenase 1-positive breast cancers are characterized by negative estrogen receptor, positive human epidermal growth factor receptor type 2, and high Ki67 expression. Cancer science. 2009; 100(6):1062-1068.

125. Charafe-Jauffret E, Ginestier C, Iovino F, Tarpin C, Diebel M, Esterni B, Houvenaeghel G, Extra JM, Bertucci F, Jacquemier J, Xerri L, Dontu G, Stassi G, et al. Aldehyde dehydrogenase 1-positive cancer stem cells mediate 
metastasis and poor clinical outcome in inflammatory breast cancer. Clinical cancer research. 2010; 16(1):45-55.

126. Liu Y, Lv DL, Duan JJ, Xu SL, Zhang JF, Yang XJ, Zhang $\mathrm{X}$, Cui YH, Bian XW and Yu SC. ALDH1A1 expression correlates with clinicopathologic features and poor prognosis of breast cancer patients: a systematic review and meta-analysis. BMC cancer. 2014; 14:444.

127. Eirew P, Kannan N, Knapp DJ, Vaillant F, Emerman JT, Lindeman GJ, Visvader JE and Eaves CJ. Aldehyde dehydrogenase activity is a biomarker of primitive normal human mammary luminal cells. Stem Cells. 2012; 30(2):344-348.

128. Meyer MJ, Fleming JM, Lin AF, Hussnain SA, Ginsburg E and Vonderhaar BK. CD44posCD49fhiCD133/2hi defines xenograft-initiating cells in estrogen receptor-negative breast cancer. Cancer Res. 2010; 70(11):4624-4633.

129. Morrison BJ, Schmidt CW, Lakhani SR, Reynolds BA and Lopez JA. Breast cancer stem cells: implications for therapy of breast cancer. Breast Cancer Res. 2008; 10(4):210.

130. Blagosklonny MV. Target for cancer therapy: proliferating cells or stem cells. Leukemia. 2006; 20(3):385-391.

131. Blagosklonny MV. Cancer stem cell and cancer stemloids: from biology to therapy. Cancer biology \& therapy. 2007; 6(11):1684-1690

132. Lawson DA, Bhakta NR, Kessenbrock K, Prummel KD, Yu Y, Takai K, Zhou A, Eyob H, Balakrishnan S, Wang CY, Yaswen P, Goga A and Werb Z. Single-cell analysis reveals a stem-cell program in human metastatic breast cancer cells. Nature. 2015; 526(7571):131-135.

133. Norgaard JM, Olesen LH and Hokland P. Changing picture of cellular drug resistance in human leukemia. Crit Rev Oncol Hematol. 2004; 50(1):39-49.

134. Doyle LA, Yang W, Abruzzo LV, Krogmann T, Gao Y, Rishi AK and Ross DD. A multidrug resistance transporter from human MCF-7 breast cancer cells. Proc Natl Acad Sci U S A. 1998; 95(26):15665-15670.

135. Ting AH, McGarvey KM and Baylin SB. The cancer epigenome--components and functional correlates. Genes Dev. 2006; 20(23):3215-3231.

136. Massard C, Deutsch E and Soria JC. Tumour stem celltargeted treatment: elimination or differentiation. Ann Oncol. 2006; 17(11):1620-1624.

137. Blevins MA, Towers CG, Patrick AN, Zhao R and Ford HL. The SIX1-EYA transcriptional complex as a therapeutic target in cancer. Expert Opin Ther Tar. 2015; 19(2):213225.

138. Liu Y, Han N, Zhou S, Zhou R, Yuan X, Xu H, Zhang C, Yin $\mathrm{T}$ and $\mathrm{Wu} \mathrm{K}$. The DACH/EYA/SIX gene network and its role in tumor initiation and progression. International journal of cancer. 2016; 138(5):1067-1075.

139. Wu KM, Li ZM, Cai SX, Tian LF, Chen K, Wang J, $\mathrm{Hu}$ JB, Sun Y, Li X, Ertel A and Pestell RG. EYA1 Phosphatase Function Is Essential to Drive Breast Cancer Cell Proliferation through Cyclin D1. Cancer Res. 2013;
73(14):4488-4499.

140. Iwanaga R, Wang CA, Micalizzi DS, Harrell JC, Jedlicka P, Sartorius CA, Kabos P, Farabaugh SM, Bradford AP and Ford HL. Expression of Six1 in luminal breast cancers predicts poor prognosis and promotes increases in tumor initiating cells by activation of extracellular signal-regulated kinase and transforming growth factor-beta signaling pathways. Breast Cancer Res. 2012; 14(4):R100.

141. Yan W, Wu K, Herman JG, Brock MV, Fuks F, Yang L, Zhu H, Li Y, Yang Y and Guo M. Epigenetic regulation of DACH1, a novel Wnt signaling component in colorectal cancer. Epigenetics. 2013; 8(12):1373-1383.

142. Liu Y, Zhou R, Yuan X, Han N, Zhou S, Xu HX, Guo MZ, Yu SY, Zhang CT, Yin TJ and Wu KM. DACH1 is a novel predictive and prognostic biomarker in hepatocellular carcinoma as a negative regulator of $\mathrm{Wnt} /$ beta-catenin signaling. Oncotarget. 2015; 6:8621-8634. doi: 10.18632/ oncotarget.3281.

143. Wu KM, Li AP, Rao M, Liu MR, Dailey V, Yang Y, Di Vizio D, Wang CG, Lisanti MP, Sauter G, Russell RG, Cvekl A and Pestell RG. DACH1 is a cell fate determination factor that inhibits cyclin D1 and breast tumor growth. Mol Cell Biol. 2006; 26(19):7116-7129.

144. Wu K, Chen K, Wang C, Jiao X, Wang L, Zhou J, Wang J, Li Z, Addya S, Sorensen PH, Lisanti MP, Quong A, Ertel A et al. Cell fate factor DACH1 represses YB-1-mediated oncogenic transcription and translation. Cancer Res. 2014; 74(3):829-839.

145. Dontu G, Jackson KW, McNicholas E, Kawamura MJ, Abdallah WM and Wicha MS. Role of Notch signaling in cell-fate determination of human mammary stem/progenitor cells. Breast Cancer Res. 2004; 6(6):R605-615.

146. Harrison H, Farnie G, Howell SJ, Rock RE, Stylianou S, Brennan KR, Bundred NJ and Clarke RB. Regulation of breast cancer stem cell activity by signaling through the Notch4 receptor. Cancer Res. 2010; 70(2):709-718.

147. Takebe N, Miele L, Harris PJ, Jeong W, Bando H, Kahn M, Yang SX and Ivy SP. Targeting Notch, Hedgehog, and Wnt pathways in cancer stem cells: clinical update. Nat Rev Clin Oncol. 2015; 12(8):445-464.

148. Saito N, Fu J, Zheng S, Yao J, Wang S, Liu DD, Yuan Y, Sulman EP, Lang FF, Colman H, Verhaak RG, Yung WK and Koul D. A high Notch pathway activation predicts response to gamma secretase inhibitors in proneural subtype of glioma tumor-initiating cells. Stem Cells. 2014; 32(1):301-312.

149. Hassan KA, Wang L, Korkaya H, Chen G, Maillard I, Beer DG, Kalemkerian GP and Wicha MS. Notch pathway activity identifies cells with cancer stem cell-like properties and correlates with worse survival in lung adenocarcinoma. Clin Cancer Res. 2013; 19(8):1972-1980.

150. Grudzien P, Lo S, Albain KS, Robinson P, Rajan P, Strack PR, Golde TE, Miele L and Foreman KE. Inhibition of Notch signaling reduces the stem-like population of 
breast cancer cells and prevents mammosphere formation. Anticancer Res. 2010; 30(10):3853-3867.

151. Abel EV, Kim EJ, Wu J, Hynes M, Bednar F, Proctor E, Wang L, Dziubinski ML and Simeone DM. The Notch pathway is important in maintaining the cancer stem cell population in pancreatic cancer. PLoS One. 2014; 9(3):e91983.

152. Pandya K, Meeke K, Clementz AG, Rogowski A, Roberts J, Miele L, Albain KS and Osipo C. Targeting both Notch and ErbB-2 signalling pathways is required for prevention of ErbB-2-positive breast tumour recurrence. Br J Cancer. 2011; 105(6):796-806.

153. Osipo C, Patel P, Rizzo P, Clementz AG, Hao L, Golde TE and Miele L. ErbB-2 inhibition activates Notch-1 and sensitizes breast cancer cells to a gamma-secretase inhibitor. Oncogene. 2008; 27(37):5019-5032.

154. Yun J, Pannuti A, Espinoza I, Zhu H, Hicks C, Zhu X, Caskey M, Rizzo P, D’Souza G, Backus K, Denning MF, Coon J, Sun M, et al. Crosstalk between PKCalpha and Notch-4 in endocrine-resistant breast cancer cells. Oncogenesis. 2013; 2:e60.

155. Zhang CC, Yan Z, Zong Q, Fang DD, Painter C, Zhang Q, Chen E, Lira ME, John-Baptiste A and Christensen JG. Synergistic effect of the gamma-secretase inhibitor PF-
03084014 and docetaxel in breast cancer models. Stem Cells Transl Med. 2013; 2(3):233-242.

156. Zhang S, Chung WC, Miele L and Xu K. Targeting Met and Notch in the Lfng-deficient, Met-amplified triple-negative breast cancer. Cancer Biol Ther. 2014; 15(5):633-642.

157. Merchant AA and Matsui W. Targeting Hedgehog--a cancer stem cell pathway. Clin Cancer Res. 2010; 16(12):31303140 .

158. Kiesslich T, Berr F, Alinger B, Kemmerling R, Pichler M, Ocker $M$ and Neureiter D. Current status of therapeutic targeting of developmental signalling pathways in oncology. Curr Pharm Biotechnol. 2012; 13(11):2184-2220.

159. Ramaswamy B, Lu Y, Teng KY, Nuovo G, Li X, Shapiro $\mathrm{CL}$ and Majumder S. Hedgehog signaling is a novel therapeutic target in tamoxifen-resistant breast cancer aberrantly activated by PI3K/AKT pathway. Cancer Res. 2012; 72(19):5048-5059. 